\title{
PELATIHAN JARIMATIKA UNTUK GURU DAN SISWA SD N DONOTIRTO KASIHAN BANTUL
}

\section{(TRAINING ON JARIMATIKA FOR TEACHERS AND STUDENTS OF DONOTIRTO STATE PRIMARY SCHOOL KASIHAN BANTUL)}

\author{
Danuri $^{1}$, Wahyu Nugroho ${ }^{2}$ \\ 1,2 Pendidikan Guru Sekolah Dasar, Universitas PGRI Yogyakarta \\ Jl. PGRI 1 No 117 Yogyakarta \\ ${ }^{1}$ Email: danuri@upy.ac.id
}

\begin{abstract}
ABSTRAK
Tujuan pengabdian ini adalah untuk: 1) memberi pengetahuan dasar tentang operasi hitung Matematika dalam menyelesaikan perkalian dengan jari-jari. 2) menghasilkan modul yang baik kepada para peserta siswa agar siswa memperoleh nilai yang maksimal dalam mengerjakan soal matematika. Metode yang digunakan adalah metode ceramah, praktek, tanya jawab, diskusi dan latihan dengan menggunakan modul jarimatika yang telah disiapkan. Pelatihan jarimatika dengan sistem kelas dengan menggunakan modul dan latihan. Pembinaan dan pelatihan yang diberikan adalah progam pengembangan diri mata pelajaran matematika pada materi operasi hitung perkalian. Pelatihan Jarimatika ini bertempat di SD N Donotirto Kasihan Bantul dengan jumlah peserta sebanyak 24 orang siswa dan Guru. Hasil dari pengabdian ini adalah: 1) Memberikan materi dan latihan operasi hitung perkalian matematika dengan metode jarimatika kepada Guru dan Siswa. 2) Melalui modul jarimatika dapat memberikan pengetahuan, pemahaman yang benar pada guru dan siswa. Dampak dari kegiatan ini adalah guru dan siswa dapat memahami materi operasi hitung perkalian matematika secara benar, dan memiliki motivasi tinggi untuk mewujudkan nilai matematika yg bagus. Kemampuan Guru untuk memotivasi seluruh siswanya agar terhindar dari kegagalan dalam menyelesaikan operasi hitung perkalian.
\end{abstract}

Kata Kunci: Pelatihan, Jarimatika, Guru dan Siswa

\begin{abstract}
This community service is intended to: 1) deliver the introductory knowledge of the basic mathematical operation to learn multiplication by using fingers. 2) to generate a proper module for students to achieve maximum score dealing with multiplication. The methods used were lecturing, practical, discussion, and exercise using the Jarimatika module which had been previously prepared. The coaching was a selfdevelopment program on the mathematic subject of multiplication. The training was set at Donotirto State Primary School Bantul were 24 students including teachers took part in the program. The results are 1) to provide material and Jarimatika multiplication exercises for students and teachers. 2) Jarimatika Module gives a contribution to teachers' knowledge and understanding of the mathematic subject matter. The activity gives an impact on teachers and students to properly apprehend the multiplication operation which accordingly cultivates students' motivation in
\end{abstract}


learning mathematics. To avoid the failure in learning, teachers should be able to foster students' motivation to learn mathematic more specifically the multiplication operation.

keyword: training, jarimatika, teachers, and students.

\section{PENDAHULUAN}

Salah satu peningkatan mutu matematika yaitu dengan mempelajari hal yang mendasar dalam matematika (Jana \& Rahmawan, 2019). Ada banyak ide yang dapat dipelajari sebagai dasar dalam matematika. Ide ide ini sering muncul dalam daftar "keterampilan dasar". Sebagai contoh, anak anak harus dapat menghitung dengan benar, mengetahui fakta fakta dasar untuk penjumlahan dan perkalian, mempunyai metode yang efisien untuk menghitung bilangan asli, pecahan dan decimal (Walle, 2008). Keterampilan dasar adalah standar minimal bagi peserta didik di pendidikan dasar untuk melanjutkan pada pendidikan menengah. Salah satu keterampilan dasar yang penting adalah perkalian. Menyadari jika perkalian adalah suatu keterampilan dasar dalam matematika, maka siswa dituntut untuntuk memahami secara baik materi perkalian dalam hal konsep (Jana, 2018).

Perkalian termasuk topik yang sulit untuk dipahami sebagian siswa sekolah dasar (Pamungkas \& Jana, 2018). Seringkali ditemukan banyak siswa di tingkatan atas sekolah dasar belum menguasai topik perkalian ini, sehingga mereka banyak mengalami kesulitan dalam mempelajari topik matematika yang lebih tinggi. Salah satu kesulitan utama dalam mengajarkan perkalian adalah memahami konsep. Pada umumnya siswa sekolah dasar diwajibkan untuk menghafal perkalian bilangan dari 1 hingga 9. Hal ini sangat berguna untuk memperkuat kecepatan dalam menyelesaikan masalah perhitungan perkalian dari yang mudah hingga yang sulit. Perkalian dasar haruslah diingat di luar kepala karena perkalian dasar akan selalu digunakan hingga pendidikan di perguruan tinggi. Mengingat pentingnya akan pemahaman perkalian matematika untuk sekolah dasar, pengabdi melakukan pelatihan langsung dilapangan.

Tujuan pengabdian ini adalah untuk:1) memberi pengetahuan dasar tentang operasi hitung Matematika dalam menyelesaikan perkalian dengan jari-jari. 2) menghasilkan modul yang baik kepada para peserta siswa agar siswa memperoleh nilai yang maksimal dalam mengerjakan soal matematika. Target luaran dari solusi yang ditawarkan kepada mitra adalah sebagai berikut guru dan Siswa mengetahui dan memahami tentang materi jarimatika 
serta dapat memahami konsep, mampu menggunakan jari secara tepat dalam melakukan operasi hitung perkalian. luaran dari kegiatan ini adalah berupa modul jarimatika dan meningkatnya pemahaman dan keterampilan peserta didik pada mata pelajaran matematika SD.

\section{METODE PELAKSANAAN}

Metode yang digunakan berupa pelatihan dan pembinaan. Pengabdian dilaksanakan pada tanggal 12 dan 13 September 2018, durasi pelaksanaan pelatihan jarimatika bersekitar 2 jam untuk 2 hari dilakukan oleh dua orang. Pelatihan jarimatika mata pelajaran Matematika SD kelas IV dilaksanakan dengan sistem kelas dengan metode menggunakan modul dan latihan. Pembinaan dan phasilelatihan yang diberikan adalah progam pengembangan diri mata pelajaran matematika pada materi operasi hitung perkalian.

Sasaran kegiatan pengabdian kepada masyarakat ini adalah Guru dan peserta didik kelas IV SD N Donotirto. Sebelum pelaksanaan pengabdian, pengabdi meminta data dari sekolah mengenai peserta didik yang akan dibina berdasarkan kelas dan pertimbangan guru. Pada pertemuan pertama, setelah peserta sudah didapatkan mulai pembinaan dan pelatihan secara intensif include dikegiatan pembelajaran. Pada pertemuan kedua setelah pembinaan selama dua pertemuan dilakukan posttest untuk menguji/menilai sejauh mana perkembangan pemahaman peserta pembinaan diakhir sesi dilakukan pembahasan.

Tahap pelaksanaan dilakukan setelah seluruh tahap persiapan selesai. Dalam tahap ini dilakukan adalah sebagai berikut. Kegiatan pelatihan jarimatika ini akan dilakukan dalam tiga tahap. Tahap persiapan yang dilakukan meliputi : Survey, Pemantapan dan penetuan lokasi dan sasaran, Penyusunan bahan/materi pelatihan, yang meliputi modul untuk kegiatan. Tahap pelaksanaan dilakukan setelah seluruh tahap persiapan selesai. Dalam tahap ini dilakukan adalah sebagai berikut; 1) Penjelasan tentang materi yang menitik beratkan pada pemahaman secara teorits dan teknis mengenai Jarimatika. 2) Penjelasan tentang cara menyelesaikan soal operasi hitung perkalian, sesi pelatihan ini mentikberatkan pada cara teknis penyelesaiaan dengan cara cepat dan benar dengan menggunakanjari-jari.

Untuk melaksanakan kegiatan tersebut digunakan beberapa metode pelatihan, yaitu metode ceramah. Metode ceramah dipilih untuk memberikan penjelasan tentang jarimatika juga digunakan untuk memotivasi siswa agar mau mencoba untuk menyelesaikan soal secara individu. Metode tanya jawab sangat penting bagi para peserta didik, baik di saatmenerima penjelasan tentang materi serta saat mempraktekkannya. Metode ini memungkinkan siswa 


\section{Jurnal Berdaya Mandiri}

Vol. 2 No. 1 Tahun 2020

E-ISSN: 2685-8398

menggali pengetahuan sebanyak-banyaknya tentang soal operasi hitung dan penyelesaiannya.

Partisipasi mitra dalam hal ini SD N Donotirto adalah menyediakan tempat untuk pengabdian, memberikan ijin pelaksanaan pengabdian. Keberhasilan kegiatan pengabdian masyarakat ini akan dievaluasi dengan mengamati hasil dari pekerjaan siswa.

\section{HASIL DAN PEMBAHASAN}

Pelatihan Jarimatika telah dilaksanakan pada tanggal 12 dan 13 September 2018 bertempat di SD N Donotirto ini dapat berjalan dengan baik dan lancar, pengabdian ini telah mampu memberikan bekal pengetahuan siswa tentang bagaimana materi dan menyelesaikan soal-soal Jarimatika pada mata pelajaran matematika dengan baik.

Sebelum pelaksanaan pengabdian, pengabdi meminta data dari sekolah mengenai peserta didik yang akan dibina berdasarkan kelas dan pertimbangan guru. Pada pertemuan pertama, setelah peserta sudah didapatkan mulai pembinaan dan pelatihan secara intensif include dikegiatan pembelajaran. Pada pertemuan kedua setelah pembinaan selama dua pertemuan dilakukan posttest untuk menguji/menilai sejauh mana perkembangan pemahaman peserta pembinaan diakhir sesi dilakukan pembahasan.

Tahap pelaksanaan dilakukan setelah seluruh tahap persiapan selesai. Dalam tahap ini dilakukan adalah sebagai berikut. Kegiatan pelatihan jarimatika ini akan dilakukan dalam tiga tahap. Berikut ini adalah tahapan pelatihan yang dilakukan:

a. Tahap Persiapan, Tahap persiapan yang dilakukan meliputi : Survey, Pemantapan dan penetuan lokasi dan sasaran, Penyusunan bahan/materi pelatihan

b. Tahap Pelaksanaan, Tahap pelaksanaan dilakukan setelah seluruh tahap persiapan selesai. Dalam tahap ini dilakukan adalah penjelasan tentang materi yang menitik beratkan pada pemahaman secara teorits dan teknis mengenai Jarimatika dan penjelasan tentang cara menyelesaikan soal operasi hitung perkalian, sesi pelatihan ini mentikberatkan pada cara teknis penyelesaiaan dengan cara cepat dan benar dengan menggunakanjari-jari. 


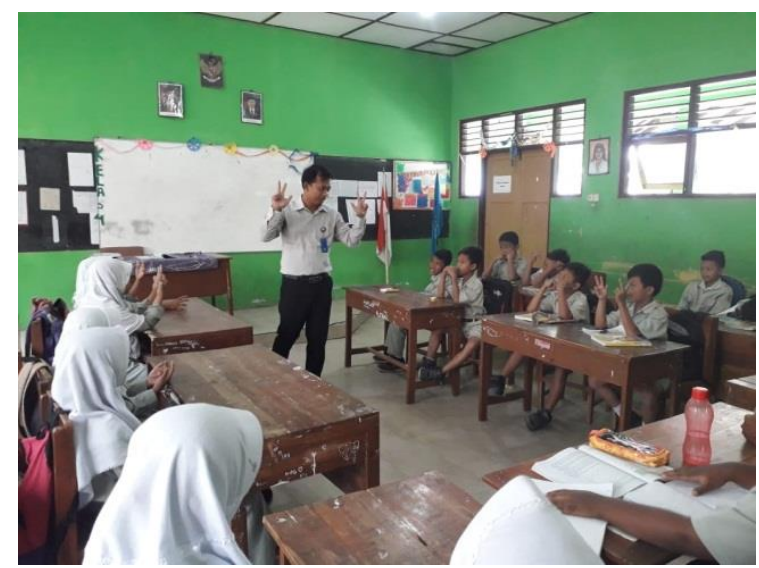

Gambar 1. Memeberikan Pelatihan Jarimatika.

c. Tahap evaluasi, Keberhasilan kegiatan pengabdian masyarakat ini akan dievaluasi dengan mengamati dan memeriksa hasil pekerjaan.

Kegiatan pelatihan jarimatika ini merupakan program pengabdian masyarakat yang diharapkan dapat memberikan pengetahuan, pemahaman yang benar pada guru dan siswa.

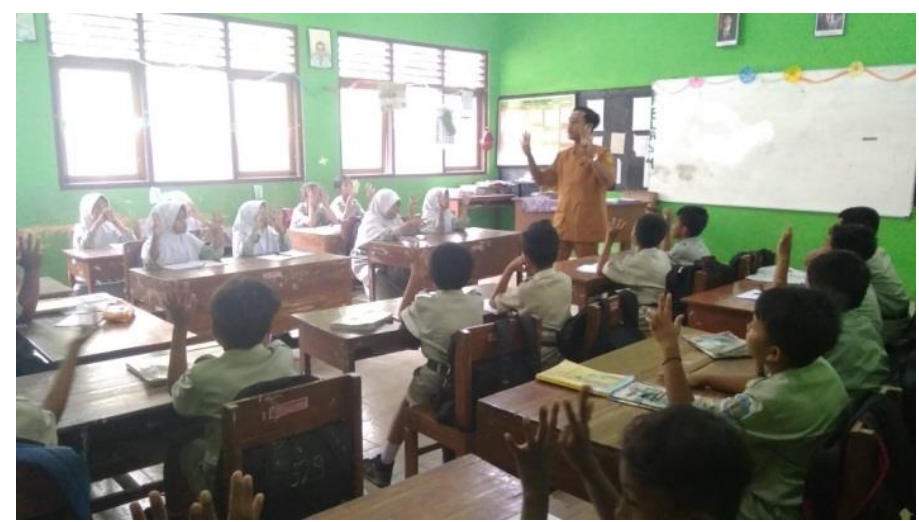

Gambar 2. Guru Mempraktikan Jarimatika.

Dampak dari kegiatan ini secara rinci adalah guru dan siswa dapat memahami materi operasi hitung perkalian matematika secara benar, dan memiliki motivasi tinggi untuk mewujudkan nilai matematika yg bagus. Kemampuan Guru untuk memotivasi seluruh siswanya agar terhindar dari kegagalan dalam menyelesaikan operasi hitung perkalian.

\section{KESIMPULAN}

Hasil dari pengabdian ini adalah 1) Memberikan materi dan latihan operasi hitung perkalian matematika dengan metode jarimatika kepada Guru dan Siswa. 2) Melalui modul jarimatika dapat memberikan pengetahuan, pemahaman yang benar pada guru dan siswa. Kegiatan Pelatihan jarimatika terlaksana dengan baik, yang dihadiri Guru kelas dan seluruh Siswa kelas IV sebanyak 24 Siswa. Melalui kegiatan tersebut dapat disimpulkan bahwa 


\section{Jurnal Berdaya Mandiri}

Vol. 2 No. 1 Tahun 2020

E-ISSN: 2685-8398

siswa memiliki pengetahuan mengenai materi dan penyelesaian soal operasi hitung perkalian matematika dengan baik dan benar.

\section{REKOMENDASI}

Follow up dari kegiatan ini adalah supaya pelatihan jarimatika pelajaran matematika untuk dapat segera ditindaklanjuti dan dilakukan secara rutin dan intensif, agar memperoleh hasil yang maksimal.

\section{UCAPAN TERIMAKASIH}

Ucapan terimakasih disampaikan kepada 1) pihak yang sepantasnya menerima ucapan tersebut, 2) Kepada lembaga atau orang yang benar-benar membantu Pengabdian kepada Masyarakat., 3) Kepada pemberi dana, fasilitas, bahan, atau saran.

\section{DAFTAR PUSTAKA}

Jana, P. (2018). Penguatan Kemampuan Matematika Dasar Siswa SMA Melalui Kegiatan Matrikulasi. MATAPPA : Jurnal Pengabdian Kepada Masyarakat, 1(1), 1-4. https://doi.org/http://dx.doi.org/10.31100/matappa.v1i1.80

Jana, P., \& Rahmawan, A. D. (2019). PENDAMPINGAN PERSIAPAN UJIAN NASIONAL BERBASIS KOMPUTER PADA SISWA SMA MUHAMMADIYAH 3 YOGYAKARTA. Jurnal Berdaya Mandiri. https://doi.org/10.31316/jbm.v1i1.298

Pamungkas, B., \& Jana, P. (2018). Workshop Penanganan Siswa Kesulitan Belajar Menghitung (Dyskalkulia) Pada Mata Pelajaran Matematika. JAIM, 1(2), 1-8. https://doi.org/http://dx.doi.org/10.30737/jaim.v1i2.151

Walle, J. A. Van de. (2008). Matematika Sekolah Dasar dan Menengah Pengembangan Pengajaran. Jakarta: Erlangga. 